\title{
ATP-dependent chromatin remodeling in the DNA-damage response
}

\author{
Hannes Lans, Jurgen A Marteijn and Wim Vermeulen ${ }^{*}$
}

\begin{abstract}
The integrity of DNA is continuously challenged by metabolism-derived and environmental genotoxic agents that cause a variety of DNA lesions, including base alterations and breaks. DNA damage interferes with vital processes such as transcription and replication, and if not repaired properly, can ultimately lead to premature aging and cancer. Multiple DNA pathways signaling for DNA repair and DNA damage collectively safeguard the integrity of DNA. Chromatin plays a pivotal role in regulating DNA-associated processes, and is itself subject to regulation by the DNA-damage response. Chromatin influences access to DNA, and often serves as a docking or signaling site for repair and signaling proteins. Its structure can be adapted by post-translational histone modifications and nucleosome remodeling, catalyzed by the activity of ATP-dependent chromatin-remodeling complexes. In recent years, accumulating evidence has suggested that ATP-dependent chromatin-remodeling complexes play important, although poorly characterized, roles in facilitating the effectiveness of the DNA-damage response. In this review, we summarize the current knowledge on the involvement of ATP-dependent chromatin remodeling in three major DNA repair pathways: nucleotide excision repair, homologous recombination, and non-homologous end-joining. This shows that a surprisingly large number of different remodeling complexes display pleiotropic functions during different stages of the DNA-damage response. Moreover, several complexes seem to have multiple functions, and are implicated in various mechanistically distinct repair pathways.
\end{abstract}

\section{DNA-damage response}

All living organisms depend on faithful preservation and transmission of genetic information to the next generation. Genetic information is stored within DNA, which is embedded in a dynamic nucleoprotein complex, called chromatin. The integrity of DNA is inescapably and continuously threatened by spontaneous and induced alterations to its basic structure. DNA itself is unstable and undergoes hydrolysis, which creates abasic sites and causes deamination [1]. Furthermore, cellular metabolic processes such as oxidative respiration produce oxygen radicals and other reactive molecules, which damage DNA [2]. Finally, exposure to environmental sources such as solar UV irradiation, $\times$ radiation, and numerous chemicals induces DNA injuries.

DNA damage interferes with vital processes such as transcription and replication, which may cause cells to die or senesce, thus contributing to aging [3]. Replication of damaged DNA templates severely affects the

\footnotetext{
* Correspondence: w.vermeulen@erasmusmc.nl

Department of Genetics, Medical Genetics Center, Erasmus MC, PO Box 2040, 3000 CA Rotterdam, The Netherlands
}

fidelity of the polymerases, and may result in permanent mutations or chromosomal aberrations, which are at the basis of malignant transformation. Genetic erosion and its consequences are neutralized by a variety of DNA repair and associated DNA-damage signaling pathways, collectively called the DNA-damage response (DDR) [3-6]. In this review, we will focus on three repair pathways which are among the best characterized with regard to their repair mechanisms and interactions with chromatin: nucleotide excision repair (NER), which removes helix-distorting intra-strand lesions, and homologous recombination (HR) and non-homologous endjoining (NHEJ), both of which repair double-strand breaks (DSBs).

\section{Chromatin and the DNA-damage response}

All DNA-associated processes, such as transcription, replication, recombination, and DNA repair, are for a large part regulated by the chromatin structure $[7,8]$. Because this nucleoprotein complex limits the ability of other proteins to interact with DNA, the chromatin structure needs to be modified to facilitate efficient 
access to DNA. In addition, DNA processing itself may also lead to changes in the chromatin structure and composition, such as DNA repair-associated post-translational histone modification and exchange. Based on the changes in chromatin observed after NER, it was suggested that chromatin needs to be made more accessible in order to allow efficient damage detection and repair to take place, after which the chromatin structure is restored to prevent genomic instability and possibly to preserve epigenetic information or to leave an imprint of the damage on the chromatin. Particularly for the latter step, clear evidence is available that nucleosome occupancy of repaired DNA is restored by the action of histone chaperones [9-12]. However, evidence for chromatin remodeling before or during repair seems to be more ambiguous, and difficult to include in a single overarching model.

Modification of chromatin basically occurs via two mechanisms. First, chromatin can be changed by posttranslational modification of histones through the action of histone-modifying enzymes. Second, chromatin can be altered by displacement of histones or entire nucleosomes through the action of ATP-dependent chromatinremodeling complexes and histone chaperones. Although both mechanisms are interconnected, in this review we will mainly discuss the second mechanism and focus on mammalian cells, although current knowledge in yeast will also be described. Readers interested in DDR-associated post-translational histone modifications are referred to other recent reviews on the subject [6,13-15].

\section{ATP-dependent chromatin-remodeling complexes}

A large array of different chromatin-remodeling complexes has been identified, and these play important roles in controlling gene expression by regulating recruitment and access of transcription factors [16]. In recent years, it has become clear that ATP-dependent chromatin-remodeling complexes also play important roles in the DDR. Using the energy of ATP hydrolysis, these complexes catalyze disruption of DNA-histone contacts, and can slide or evict nucleosomes or alter their composition [17-19]. Among the different complexes identified in different species, four structurally related families have been described: SWI/SNF (switching defective/sucrose nonfermenting), INO80 (inositol requiring 80), CHD (chromodomain, helicase, DNA binding) and ISWI (imitation switch) (Table 1). Each family is defined by its characteristic catalytic core ATPase enzyme from the SWI2/SNF2 superfamily. ATP-dependent chromatin-remodeling complexes have diverse but specific functions in processes involving DNA metabolism. Although some redundancy occurs, most remodelers are essential for cellular growth, development, or differentiation. Consequently, they have been implicated in many embryonic developmental processes and in tumorigenesis $[17,18]$.

\section{Chromatin and nucleotide excision repair}

NER removes a wide range of bulky DNA adducts that distort the double helix, including those induced by UV light. NER is initiated by two damage-recognition pathways, transcription-coupled (TC)-NER and global genome (GG)-NER, which remove damage in roughly four successive steps: 1) lesion detection, 2) local unwinding and damage verification, 3) excision of the DNA surrounding the lesion, and finally 4) DNA synthesis and ligation to fill the resulting gap (Figure 1) [20]. Damage that occurs in the transcribed strand of active genes is mainly repaired by TC-NER, whereas damage in nontranscribed DNA is repaired by GG-NER.

The importance of chromatin remodeling for NER is apparent from many experiments that have shown that NER is more efficient in naked DNA than in chromatin, and is inhibited by the presence of nucleosomes and heterochromatin, which limit the access of repair proteins to DNA [11,21-23]. Thus, for NER to recognize, excise, and repair DNA damage efficiently, the chromatin needs to be adapted. Conversely, DNA injuries may differentially affect chromatin structure. Although NER removes a large variety of structurally unrelated DNA lesions, including UV-induced cyclobutane pyrimidine dimers (CPDs) and 6-4 photoproducts (64PPs) [24], removal efficiency of these lesions differs significantly. For example, in non-transcribed DNA, GG-NER of 64PPs is much faster than GG-NER of CPDs [25-27]. Chromatin may exert substantial influence on this lesion-specific repair, as 64PPs seem to be predominantly formed in internucleosomal regions, whereas CPDs are formed equally in nucleosomal and internucleosomal DNA [28]. Nevertheless, in naked DNA [29] and nucleosomes [30], 64PPs are also repaired faster than CPDs. Lesion-specific differences in NER efficiency have also been explained by the degree to which they distort the helical DNA structure and define the affinity for the GG-NER initiation factor XPC [31,32]. Furthermore, repair of CPDs in non-transcribed DNA depends on the presence of the GG-NER-specific DNA damagebinding (DDB) recognition complex, which is thought to modify chromatin to facilitate binding of XPC [33-38]. In TC-NER, which is initiated upon stalling of RNA polymerase 2 after damage, different lesions are removed with equal speed $[26,39]$. This suggests that differences in repair rate are caused not only by the helix-distorting capacity and chromatin environment, but also by the manner in which lesions are detected. Lesion removal in transcribed DNA occurs more rapidly than in non-transcribed DNA [40], possibly because 
Table 1 Yeast and mammalian ATP-dependent chromatin remodeling proteins and complexes implicated in the DDR.

\begin{tabular}{|c|c|c|c|c|c|}
\hline Family & Complex & ATPase & Additional subunits & Species & Ref \\
\hline \multirow[t]{4}{*}{ SWI/SNF } & SWI/SNF & Snf2 & Swi3, Snf12, Arp7, Arp9, Snf11, Snf5, Snf6, Swi1, Swp82, Taf14 & Yeast & [157] \\
\hline & RSC & Sth1 & Rsc1-4, Rsc6, Rsc8-, Rsc9, Rsc30, Rsc58, Rsc7, Arp7, Arp9, Sfh1, Htl1, Ldb7, Rtt102 & Yeast & [157] \\
\hline & BAF & $\begin{array}{l}\text { SMARCA4/BRG1, } \\
\text { SMARCA2/BRM }\end{array}$ & $\begin{array}{l}\text { ARID1A, SMARCC2, SMARCC1, SMARCD1-3, SMARCE1, ACTL6A, SMARCB1/SNF5, } \\
\text { BAF45a-d, BRD7, BRD9, ACTB }\end{array}$ & Mammal & {$[17,157]$} \\
\hline & PBAF & $\begin{array}{l}\text { SMARCA4/BRG1, } \\
\text { SMARCA2/BRM }\end{array}$ & $\begin{array}{l}\text { ARID2, PBRM1, SMARCC2, SMARCC1, SMARCD1-3, SMARCE1, ACTL6A, } \\
\text { SMARCB1/SNF5, BAF45, BRD7, BRD9, ACTB }\end{array}$ & Mammal & [157] \\
\hline \multirow[t]{4}{*}{ INO80 } & INO80 & $\operatorname{lno80}$ & Arp4, Arp5, Arp8, Act1, Rvb1, Rvb2, Taf14, les1-6, Nhp10 & Yeast & {$[158]$} \\
\hline & SWR1 & Swr1 & Arp4, Arp6, Act1, Rvb1, Rvb2, Yaf9, Vps71, Vps72, Swc3-5, Swc7, Bdf1 & Yeast & {$[17,158]$} \\
\hline & INO80 & INO80 & $\begin{array}{l}\text { RUVBL1, RUVBL2, ACTL6A, ACTR5/Arp5, ACTR8/Arp8, INO80B, INO80C, TFPT, } \\
\text { NFRKB, MCRS1, INO80E, INO80D }\end{array}$ & Mammal & [17] \\
\hline & $\begin{array}{l}\text { TRRAP/ } \\
\text { Tip60' }\end{array}$ & $\mathrm{EP} 400 / \mathrm{p} 400$ & $\begin{array}{l}\text { RUVBL1, RUVBL2, KAT5/Tip60, ACTL6A, ACTB, YEATS4, DMAP1, VPS72, BRD8, } \\
\text { MORF4L1, MORF4L2, MEAF6, C20orf20, EPC1, EPC2, ING3 }\end{array}$ & Mammal & [17] \\
\hline \multirow[t]{2}{*}{$\mathrm{CHD}$} & NuRD & $\mathrm{CHD} 3, \mathrm{CHD} 4$ & MBD2, MBD3, MTA1-3, HDAC1, HDAC2, RBBP7, RBBP4, GATAD2A, GATAD2B & Mammal & {$[17,159]$} \\
\hline & & $\mathrm{CHD}^{2}$ & & Mammal & [137] \\
\hline \multirow[t]{7}{*}{ ISWI } & ISWla & Isw1 & loc3 & Yeast & [160] \\
\hline & $|S W| b$ & Isw1 & loc2, loc4 & Yeast & {$[160]$} \\
\hline & ISW2 & Isw2 & Itc1, Dpb4, Dls1 & Yeast & {$[17,160]$} \\
\hline & $A C F$ & SMARCA5/hSNF2H & BAZ1A/hACF1 & Mammal & {$[17,160]$} \\
\hline & CHRAC & SMARCA5/hSNF2H & BAZ1A/hACF1, CHRAC1, POLE3 & Mammal & {$[17,160]$} \\
\hline & WICH & SMARCA5/hSNF2H & BAZ1B/WSTF & Human & {$[17,160]$} \\
\hline & NURF & SMARCA1/hSNF2L & BPTF, RBBP7, RBBP4 & Mammal & {$[17,160]$} \\
\hline \multirow[t]{11}{*}{ Uncategorized } & & Rad16 & & Yeast & {$[48,49]$} \\
\hline & & $\operatorname{Rad} 26$ & & Yeast & [161] \\
\hline & & Rad5 & & Yeast & {$[162]$} \\
\hline & & Rdh54 & & Yeast & {$[163,164]$} \\
\hline & & CHD1L/ALC1 & & Mammal & {$[132,133]$} \\
\hline & & $\mathrm{ERCC6/CSB}$ & & Mammal & {$[165]$} \\
\hline & & HLTF & & Mammal & {$[166,167]$} \\
\hline & & RAD54L & & Mammal & {$[90,168]$} \\
\hline & & RAD54B & & Mammal & [169-171] \\
\hline & & SHPRH & & Mammal & {$[167,172]$} \\
\hline & & SMARCAL1 & & Mammal & {$[173,174]$} \\
\hline
\end{tabular}

See main text for references in which the different ATP-dependent chromatin-remodeling complexes are implicated in the DNA-damage response.

both GG-NER and TC-NER remove these lesions, but possibly also because chromatin has already been made more accessible by the transcription machinery.

\section{ATP-dependent chromatin remodeling during nucleotide excision repair}

UV damage itself enhances unwrapping of nucleosomes, which normally exist in a dynamic equilibrium between wrapping and unwrapping [41]. This enhanced 'DNA breathing' may assist the repair of lesions in chromatin by increasing the time window for repair factor access and binding of these repair proteins to lesions might further unwrap the DNA. Additionally, access to DNA is likely to be actively induced by multiple ATP-dependent chromatin-remodeling complexes, which have been implicated in the response of cells to UV irradiation (Table 1). One of the major TC-NER proteins, CSB/ ERCC6, contains a SWI2/SNF2 ATPase domain, which is essential for recruitment of the protein to chromatin and to its function in repair [42-45]. CSB is able to remodel chromatin in vitro in an ATP-dependent fashion [46], and is required for the recruitment of NER factors to sites of TC-NER [47], but its precise activity and whether it remodels nucleosomes during TC-NER in vivo remains unknown. Another NER factor, Rad16, which is essential for GG-NER in yeast, also contains a SWI2/SNF2 domain $[48,49]$. Although Rad16 does not slide or evict nucleosomes, it affects chromatin structure through its DNA translocase activity $[50,51]$ and by controlling UV-induced histone $\mathrm{H} 3$ acetylation induced by the histone acetyltransferase Gcn5 [52-54].

\section{SWI/SNF}

Accumulating evidence suggests that chromatin is remodeled by SWI/SNF complexes during NER, leading to chromatin relaxation and increased access to DNA of 


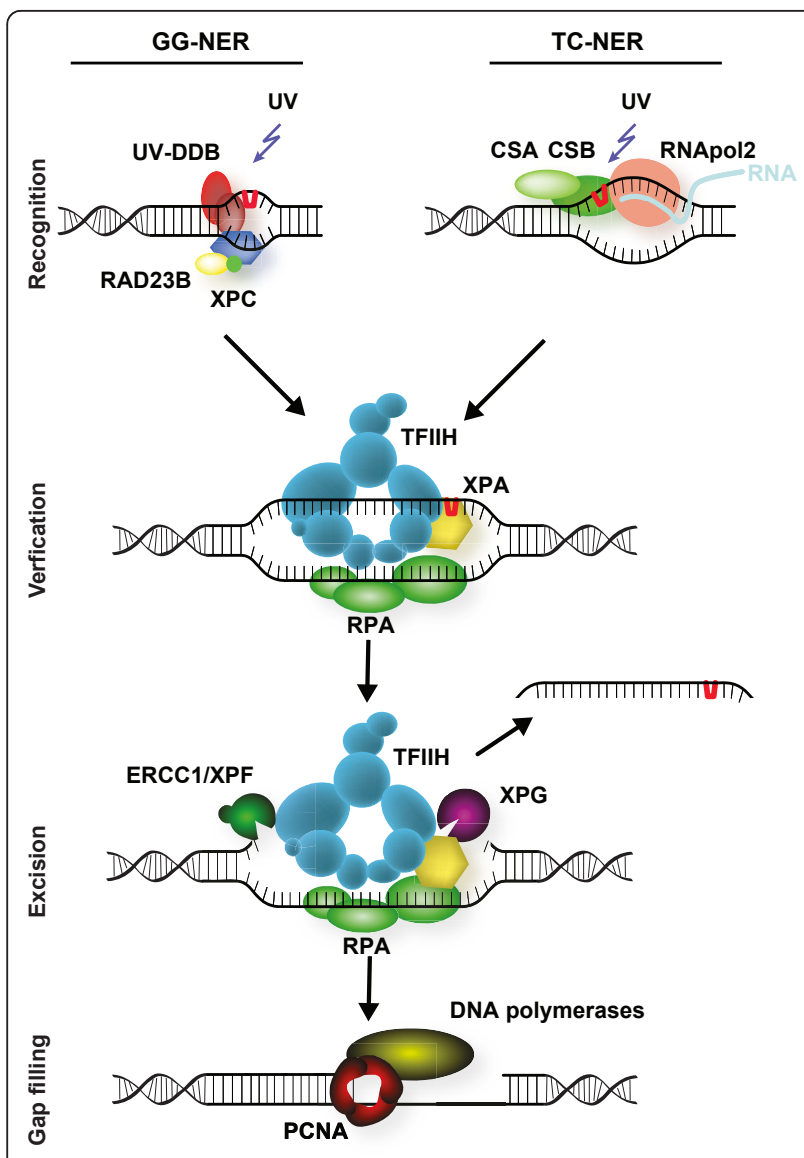

Figure 1 Mammalian nucleotide excision repair (NER). NER removes a wide variety of helix-distorting lesions from DNA, including those induced by UV light [20]. NER is executed by two different damage-detection mechanisms, which utilize the same machinery to excise and repair the damage. Transcription-coupled NER (TC-NER) is initiated by stalling of RNA polymerase 2 on a lesion present in the transcribed strand of active genes, and depends on recruitment of the CSA and CSB proteins. Other lesions are removed by global genome NER (GG-NER), which is initiated by the UV-DDB ubiquitin ligase complex and the heterotrimeric XPC/ RAD23/CETN2 complex. Following detection, the transcription factor II H (TFIIH) complex is recruited, and unwinds a stretch of approximately 30 nucleotides around the damage, providing access for other repair factors. The DNA-binding proteins XPA and RPA are thought to stimulate the translocation and damage-verification activity of TFIIH and to stabilize and orient the XPF/ERCC1 and XPG endonucleases, which subsequently incise the DNA around the damage. After excision of the damaged strand, the resulting gap of 25 to 29 nucleotides is filled in by DNA synthesis and ligation, involving replication factors such as PCNA and RFC, DNA polymerases $\delta, \varepsilon$ and $\kappa$, and final sealing of the gap by DNA ligases I and III. For clarity, not all proteins known to be involved in NER are shown.

NER initiation factors. In vitro, NER-mediated excision of acetylaminofluorene-guanoside or 64PP lesions within nucleosomal templates is stimulated by purified yeast SWI/SNF $[55,56]$. In yeast, the NER initiation complex Rad4-Rad23, orthologous to mammalian XPC/RAD23B, interacts with Snf5 and Snf6, two SWI/SNF complex subunits, in a UV-specific manner [57]. Furthermore, Snf6 and the ATPase Swi2 are required for UV-induced increase in chromatin accessibility, which is also associated with hyperacetylation of histones $\mathrm{H} 3$ and $\mathrm{H} 4$ $[52,57]$. Likewise, in mammals, the SWI/SNF ATPase BRG1/SMARCA4 stimulates efficient repair of CPDs but not of 64PPs $[58,59]$, and associates with the recognition factors DDB2 [58] and XPC [59]. However, conflicting results have been reported about whether BRG1 stimulates recruitment of XPC to sites of DNA damage or, vice versa, whether XPC stimulates BRG1 recruitment, which in turn stimulates recruitment of later NER factors. Finally, BRG1 may also transcriptionally regulate the UV-induced G1/S checkpoint, as loss of BRG1 leads to increased UV-induced apoptosis [60].

Besides BRG1, the mammalian SWI/SNF subunit SNF5/SMARCB1 also interacts with XPC [61]. Inactivation of SNF5 causes UV hypersensitivity and inefficient CPD repair [60,62], although this has been challenged by a study in which no effect of SNF5 depletion on UV sensitivity was found [63]. These differences may be due to the use of different assays and cells. In a genetic screen, our laboratory identified different subunits of SWI/SNF complexes, including orthologs of mammalian BRG1 and BRM/SMARCA2, SNF5, PBRM1 and BAF155/SMARCC1, which are essential for optimal UV survival of somatic cells in Caenorhabditis elegans [64]. Intriguingly, BRG1/BRM, but none of the other subunits, is also important to the UV response of germ cells, suggesting that the involvement of individual SWI/SNF subunits may differ between cell types. Importantly, UV hypersensitivity resulting from BRG1 inactivation depends on the presence of the checkpoint protein TP53 [58], extending the complexity of the involvement of BRG1 in UV-induced DDR. How exactly SWI/SNF remodelers impinge on NER is as yet unknown, but the available data support a regulatory role in the damagedetection step of NER (Figure 2).

\section{INO80}

The INO80 chromatin-remodeling complex probably also remodels chromatin during NER (Figure 2). Both yeast ino80 mutants and mammalian INO80-deficient cells are sensitive to UV irradiation [65,66]. Yeast Ino80 interacts with $\operatorname{Rad} 4$ and $\operatorname{Rad} 23$, and is recruited to damaged chromatin in a Rad4-dependent manner, where it is required for restoration of repair-induced nucleosome loss [67]. Whether yeast Ino80 is also involved in earlier repair events is controversial $[67,68]$. The mammalian INO80 complex functions during earlier NER steps because it facilitates the recruitment of early NER factors such as XPC and XPA, and, in contrast to yeast, localizes to damaged DNA independently 


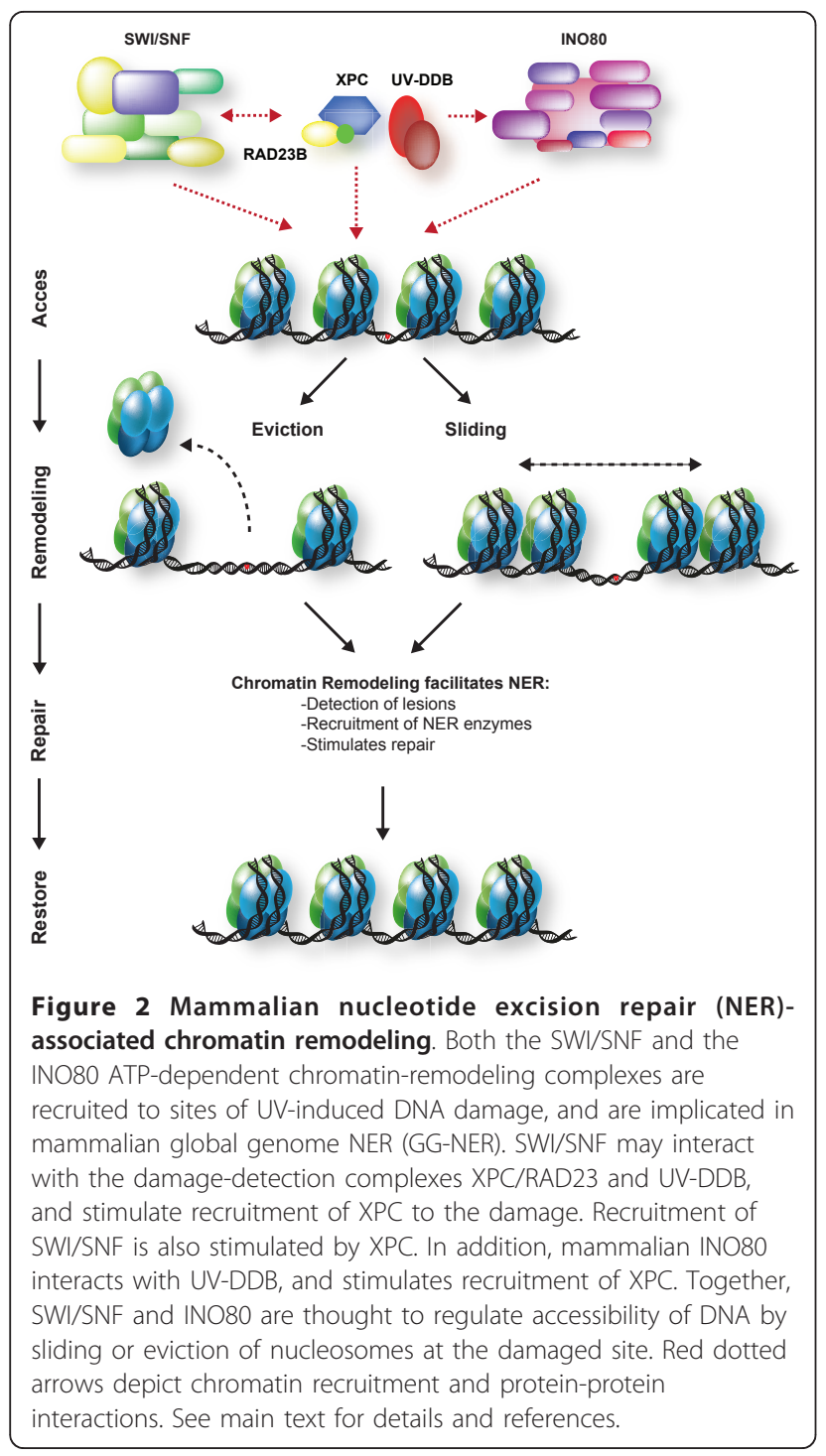

of XPC [69]. Furthermore, INO80 facilitates efficient 64PP and CPD removal and, together with the Arp5/ ACTR5 subunit, interacts with the NER initiation factor DDB1, but not with XPC. These discrepancies may reflect interspecies differences, but may also point to multiple functions of INO80 chromatin remodeling during NER that are experimentally difficult to dissect. INO80 may function to facilitate damage detection as well as to restore chromatin after damage is repaired.

\section{ISWI}

Several experiments have suggested that ISWI-mediated chromatin remodeling also functions to regulate NER, although its precise role is still unknown. The recombinant Drosophila ISWI, ACF, stimulates NER-mediated excision of 64PP lesions in the linker DNA of reconstituted dinucleosomes, possibly through a nucleosome sliding mechanism [70]. Furthermore, we found that loss of the C. elegans ISWI ATPase isw-1 renders the nematodes sensitive to UV irradiation [64]. Knockdown of the mammalian ISWI ATPase SNF2H/SMARCA5 or its auxiliary factor ACF1/BAZ1A also leads to mild UV sensitivity [71,72]. Moreover, SNF2H interacts with CSB [73], and the ACF1 subunit is recruited to UV-induced DNA damage [74]. Further experimentation is required to understand how ISWI chromatin remodeling functions in the UV-DDR.

\section{Discussion and perspectives}

From the above overview, it is clear that some ATPdependent chromatin-remodeling complexes facilitate the early damage-recognition step of NER $[58,69]$ (Figure 2), although their precise function and their interdependence is not yet clear. This early chromatin remodeling is in line with the notion that UV-induced increase of DNA accessibility, associated with histone $\mathrm{H} 3$ and H4 hyperacetylation, precedes NER [52,75]. Other results, however, suggest that ATP-dependent chromatin remodeling depends on active NER $[59,67,76]$. Interestingly, it was shown in vitro that not only does SWI/SNF chromatin remodeling stimulate NER, but that NER factors also stimulate chromatin remodeling activity by SWI/SNF [55]. Thus, NER initiation factors and chromatin remodelers may cooperate to stimulate each other's recruitment and activity. The earliest known recognition complex in NER, UV-DDB, was suggested to recruit chromatin-remodeling factors to sites of damage $[58,69]$. However, alternative UV-DDB independent mechanisms may also be involved.

Restoration on DNA of nucleosome occupancy, the loss of which results from DNA damage and its repair, may also require ATP-dependent chromatin remodeling. However, evidence for this function is still limited as to date this has only been observed for INO80 during yeast NER [67]. The yeast and mammalian histone chaperone complex CAF-1 and possibly also ASF1 are involved in this post-repair histone deposition on newly synthesized DNA as well [12,67,77-79]. Further mechanistic studies are required to address whether and how ATP-dependent chromatin remodelers regulate nucleosome occupancy after NER, and to identify the interplay with histone chaperones in this process. Furthermore, because GG-NER and TC-NER utilize alternative DNA damage-recognition mechanisms, it will be interesting to determine differences in chromatin remodeling between these NER sub-pathways, particularly because TC-NER is associated with active transcription, and chromatin is already modified to allow access to proteins. Besides involvement of SWI/SNF and INO80 remodeling complexes, the role of other complexes, such as ISWI and CHD, needs more attention. Based on the analogy to 
DSB repair (see below), it is expected these complexes are involved in NER as well.

\section{Chromatin and double-strand break repair}

DNA DSBs can be induced by ionizing radiation and chemicals, or can occur as a consequence of replication failure. They represent a major challenge to cells, as they can directly lead to chromosome instability and large genetic alterations. DSBs are mainly repaired by either HR [80] or NHEJ [81] (Figure 3). HR is an errorfree repair pathway that preferentially utilizes a sister chromatid as template, which is only present in late Sor G2-phase of the cell cycle, to repair DNA damage. By contrast, NHEJ occurs in all phases of the cell cycle, and fuses broken DNA ends together. Prior to NHEJ-associated ligation, limited DNA end-processing may occur, and this is usually associated with loss of a few nucleotides. NHEJ is therefore a more error-prone repair process than HR. Both DSB repair mechanisms begin with detection of the break and subsequent DNA processing, especially during $\mathrm{HR}$, and these steps are associated with extensive phosphorylation and ubiquitylation events that modify the chromatin and proteins surrounding the break [15]. In the direct vicinity of the break, histone H2AX is phosphorylated by phosphatidylinositol 3kinases such as ATM and ATR, leading to recruitment of mediator factors, including the scaffold protein MDC1 and the signaling proteins BRCA1 and 53BP1/ TP53BP1 $[4,82]$.

Chromatin structure plays a major role in DSB repair and signaling. The compaction of chromatin influences the sensitivity of cells to DSBs and the efficiency of the DDR [83]. Furthermore, breaks in heterochromatin are repaired more slowly than in euchromatin and require ATM-dependent phosphorylation of the heterochromatin protein KAP1/TRIM28 [84,85]. Moreover, it has been shown that chromatin becomes more relaxed upon DSB induction [85-87] and expands locally in an ATPdependent fashion [88]. It thus appears that the effectiveness of the DSB-associated DDR is tightly regulated by the chromatin structure, and that the process itself modulates chromatin.

\section{ATP-dependent chromatin remodeling during DSB repair}

One of the key proteins in HR, RAD54, contains a functional SWI2/SNF2 ATPase domain that is essential for several of the protein's functions [89,90]. For instance, through this domain RAD54 promotes branch migration of the holiday junction, an HR intermediate crossstranded DNA structure [90,91]. Additionally, many other SWI2/SNF2 domain-containing protein complexes function during the DSB-induced DDR (Table 1).

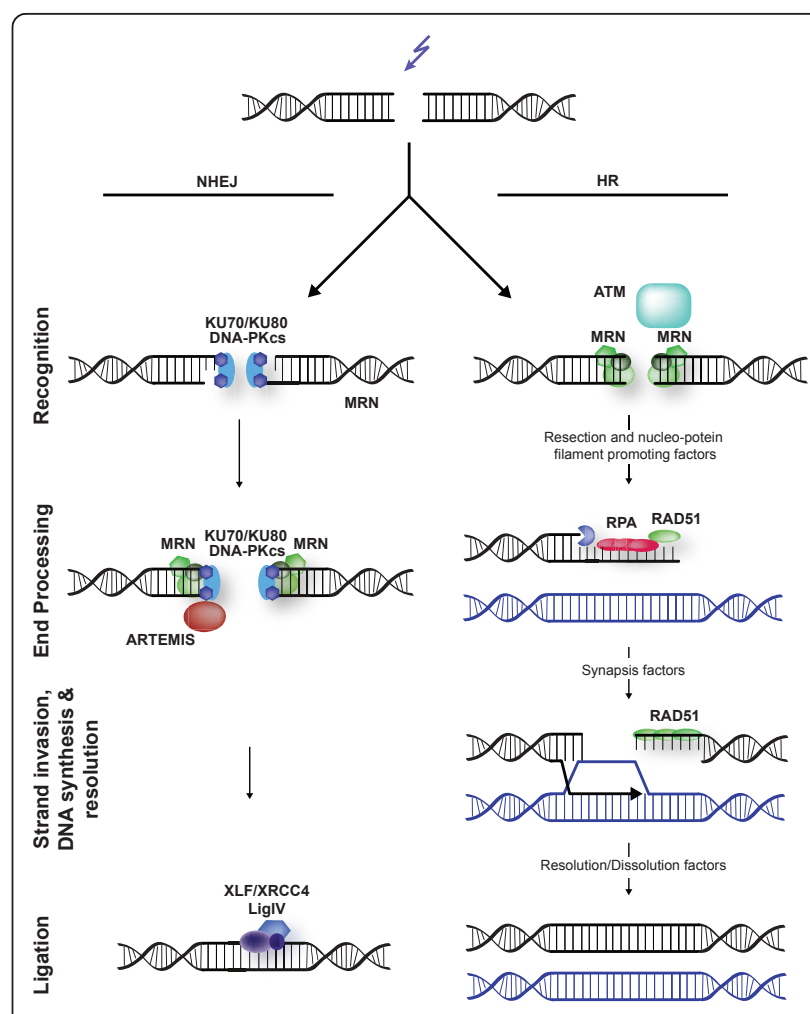

Figure 3 Mammalian double-strand break (DSB) repair. DNA DSBS are predominantly repaired by either non-homologous endjoining (NHEJ) or homologous recombination (HR) [156]. NHEJ rejoins broken DNA ends, and often requires trimming of DNA before ligation can occur. This can lead to loss of genetic information. In NHEJ, the broken DNA ends are bound by the KU70/ KU80 heterodimer, which orchestrates the activity of other repair factors and recruits the phosphatidylinositol 3-kinase DNA-PKcs/ PRKDC. DNA-PKcs phosphorylates and activates additional repair proteins, including itself and the ARTEMIS/DCLRE1C nuclease. ARTEMIS and/or the heterotrimeric MRE11-RAD50-NBN complex are thought to process the DNA ends prior to ligation. The DNA ends are joined by the activity of polymerases and a ligase complex consisting of XRCC4, XLF/NHEJ1 and LIG4. In contrast to NHEJ, HR is an error-free repair pathway that utilizes a sister chromatid, present only in the S- or G2-cell cycle phase, as template to repair DSBs. HR is initiated by DNA end-resection, involving the MRE11-RAD50-NBN complex and several accessory factors including nucleases. The MRE11-RAD50-NBN complex also recruits the phosphatidylinositol 3kinase ATM, which phosphorylates histone H2AX and many other proteins involved in repair and checkpoint signaling. Single-stranded DNA generated by DNA end-resection is bound by RPA, which is subsequently replaced by RAD51. RAD51 promotes the invasion of the single-stranded DNA to a homologous double-stranded DNA template, leading to synapsis, novel DNA synthesis, strand dissolution, and repair. Many more proteins are involved in both NHEJ and HR, which are not depicted here for clarity, as they are not referred to in the main text. For details, see recent reviews by Lieber [81] and San Filippo et al. [80].

\section{SWI/SNF}

The yeast SWI/SNF complex facilitates the pairing of homologous DNA strands during HR, and is recruited to sites of damage $[92,93]$. In addition, the SWI/SNF- 
related RSC complex in yeast is involved in DSB repair $[92,94,95]$, particularly in $\mathrm{HR}$, in which it is implicated in new DNA synthesis [92] and recombination between sister chromatids during S/G2 phase[ 96]. In addition, RSC functions in NHEJ, because recruitment of the core ATPase of RSC, Sth1, to DSBs depends on the NHEJspecific DNA end-binding protein yKu70, and two of the RSC subunits interact with yKu80 $[95,97]$. Conversely, the recruitment of $\mathrm{yKu} 70$, the endo/exonuclease Mre11 and the damage-sensor kinases Mec1 and Tel1, and the phosphorylation of $\mathrm{H} 2 \mathrm{~A}$ at DSBs are also affected by RSC subunits [97,98]. During DSB repair, RSC locally increases DNA accessibility by nucleosome displacement at the site of damage [99], which may be a means through which RSC promotes multiple steps of NHEJ and HR.

Similarly, in mammals SWI/SNF seems to regulate DDR efficiency. Interference with the two SWI/SNF catalytic ATPase subunits BRG1 and BRM sensitizes cells to DSB-inducing agents, impairs damage-induced phosphorylation of H2AX, and decreases repair [100,101]. Both proteins are recruited to damaged chromatin, and interact with acetylated $\mathrm{H} 3$ and $\mathrm{H} 4$ in nucleosomes $[102,103]$. This interaction is stimulated by phosphorylation of H2AX, and depends on the DNA damageinduced activity of acetyltransferases Gcn5, CBP/ CREBBP, and p300/EP300. SWI/SNF recruitment is also facilitated by an increased DNA damage-induced interaction with the early DDR protein BRIT1/MCPH1, which depends on phosphorylation of the SWI/SNF core protein BAF170 by ATM/ATR [104]. Furthermore, $B R M$ is required for $\mathrm{Ku} 70$ recruitment to damaged DNA and thus for efficient NHEJ [103]. Together, these results suggest that mammalian SWI/SNF functions to facilitate DSB repair, and is recruited by and stimulates phosphorylation of H2AX (Figure 4).

\section{INO80}

Multiple remodeling activities of INO80 family complexes have been reported to regulate different steps of the DSB-induced DDR. In yeast, the INO80 complex is recruited to DSBs in a $\mathrm{H} 2 \mathrm{~A}$-phosphorylation-dependent manner and is required for removal of nucleosomes at DSB sites, affecting both HR and NHEJ [65,105-111]. Likewise, the INO80-related SWR1 complex is also recruited to DSBs in a H2A-phosphorylation-dependent manner, where it may function in nucleosome remodeling to regulate DSB repair $[109,112,113]$. INO80 and SWR1 probably function antagonistically in regulating genome integrity and checkpoint adaptation, which is the escape from an extended cell cycle checkpoint $[112,114]$. INO80 promotes genome stability and checkpoint escape by exchanging the SWR1-incorporated histone variant $\mathrm{Htz}$ for $\mathrm{H} 2 \mathrm{~A}$. Other than in yeast, the

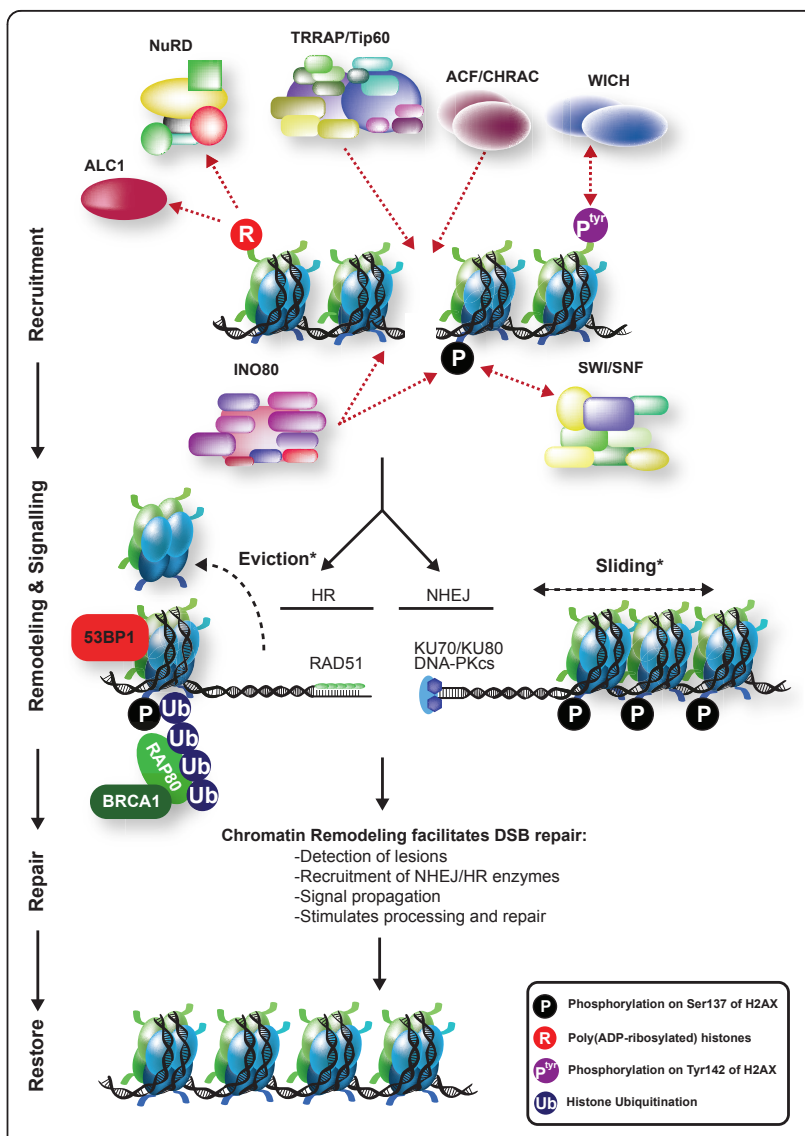

Figure 4 ATP-dependent chromatin remodeling during mammalian double-strand break (DSB) repair. A variety of ATPdependent chromatin-remodeling complexes slide, evict, and modify nucleosomes to assist DSB repair, by increasing accessibility to DNA and facilitating DNA end-resection. Recruitment of various NHEJ, HR and signaling factors, and induction and maintenance of histone modifications at the site of damage depend on the recruitment and activity of various remodeling complexes. ALC1, which regulates DSB repair, and the NuRD complex, which promotes DSB repair and aids checkpoint activation, are both recruited in a poly(ADP ribose) polymerase (PARP)-dependent manner, which may involve poly(ADP-ribos)ylation of histones. The TRRAP/Tip60 complex localizes to DSBs to acetylate histones, and promote subsequent repair and signaling events. The ACF and/or CHRAC complexes are recruited to sites of damage, and interact with KU70 to facilitate efficient NHEJ. The WICH complex phosphorylates histone H2AX in a non-canonical manner, and stimulates efficient damage signaling and recruitment of repair factors. Finally, SWI/SNF interacts with acetylated histones $\mathrm{H} 3$ and $\mathrm{H} 4$ at the site of damage and, together with INO80, facilitates phosphorylation of histone H2AX. Red dotted arrows depict chromatin recruitment and protein-protein interactions. See main text for more detail and references. *sliding and eviction mechanisms are probably involved in both NHEJ and HR.

mammalian INO80 complex is recruited to DSBs independently of phosphorylated $\mathrm{H} 2 \mathrm{AX}$ and is implicated in HR $[66,115]$, whereas another study has suggested that the core ATPase INO80 and the Arp5 subunit regulate phosphorylation of H2AX [116]. Furthermore, TIP49/ 
RUVBL1 and TIP48/RUVBL2, core subunits of the different mammalian INO80 family complexes, affect RAD51 loading onto DSB sites during HR, but do not affect phosphorylation of H2AX [117]. These findings suggests that INO80 functions during different steps of HR. Apart from a direct role in DSB repair, INO80 might also indirectly function to regulate transcription of the RAD54 and XRCC3 DSB repair genes [118].

Several subunits of the mammalian SWR1-related TRRAP-Tip60 complex, including the ATPase p400/ EP400 and the acetyltransferase Tip60/KAT5, are recruited to DSBs and locally decrease nucleosome stability [119-121]. Tip60 acetylates ATM and the histones $\mathrm{H} 2 \mathrm{~A} / \mathrm{H} 2 \mathrm{AX}$ and $\mathrm{H} 4$ after DNA damage, and is required for efficient DSB repair [120,122-125]. The activity of both p400 and Tip60 is required for subsequent steps of DSB repair, such as ubiquitylation of histones, and recruitment of the signaling proteins BRCA1 and 53BP1 $[119,120]$. Furthermore, in Drosophila, p400 and Tip60 were both shown to catalyze the exchange of the phosphorylated H2AX homolog $\mathrm{H} 2 \mathrm{Av}$ for unmodified $\mathrm{H} 2 \mathrm{Av}$ at sites of damage [125]. Together, these results indicate that different chromatin-remodeling complexes in the INO80 family perform different functions in DSB repair to make chromatin more accessible for repair and signaling factors via mechanisms of histone acetylation and nucleosome remodeling (Figure 4).

\section{CHD}

Different members of the CHD family of chromatin remodelers are involved in regulating DSB repair in chromatin. It has been shown that CHD3 is dispersed from DSBs in heterochromatin via a mechanism involving KAP-1 phosphorylation by ATM, leading to chromatin relaxation and heterochromatic DSB repair [84]. CHD3 and the related CHD4 protein can both act as the central ATPase enzyme of the NuRD complex. Loss of several subunits of the CHD4-containing NuRD complex, including CHD4 itself, leads to increased ionizing radiation sensitivity in both $C$. elegans and mammalian cells and to defective DSB repair [126-130]. Furthermore, many subunits of NuRD are recruited to DSBs in a, at least for CHD4 and MTA1, poly(ADP ribose) polymerase (PARP)-dependent manner, but surprisingly, do not require phosphorylation of H2AX [128-131]. Additionally, CHD4 and the regulatory subunit MTA2 function in ubiquitin-mediated signaling by aiding the recruitment of the E3 ligases RNF168 and BRCA1 to DSBs $[128,130]$. Finally, CHD4 depletion leads to defects in the $\mathrm{G} 1$ to $\mathrm{S}$ transition, probably by controlling deacetylation of $\mathrm{p} 53$, and in the $\mathrm{G} 2 / \mathrm{M}$ checkpoint upon DNA damage [128-130]. Together, these results suggest an important role for CHD4-containing NuRD in chromatin remodeling at the site of damage, facilitating efficient checkpoint activation (Figure 4).

Other members of the CHD family that are implicated in the DDR include the CHD1-like ATP-dependent chromatin-remodeling protein ALC1/CHD1L. ALC1 localizes to DSBs in a PARP-dependent manner, and binds the repair proteins Ku70, XRCC1 and DNA-PK $[132,133]$. ALC1 also interacts with the damagerecruited histone chaperone and DNA strand-break repair protein APLF [134], possibly to regulate NHEJ $[135,136]$. Finally, mouse cells deficient in CHD2 exhibit increased levels of spontaneous DNA damage, defective DNA-damage signaling, and sensitivity to DNA-damaging agents, suggesting a role for this protein in the DDR [137].

\section{ISWI}

Multiple ISWI family chromatin-remodeling complexes function in different steps of HR, NHEJ and damageassociated signaling. Both of the ATPases of the ISWI family complexes, SNF2H and SNF2L/SMARCA1, are recruited to DSBs and confer sensitivity to DNA damage upon knockdown $[71,72,126,138-141]$. SNF2H is recruited to sites of damage via RNF20-mediated monoubiquitylation of H2B and methylation of H3K4 [141]. Depletion of SNF2H impairs DNA end-processing, RAD51 and BRCA1 recruitment, and subsequent repair via HR. Furthermore, the ACF1 protein, which forms part of the mammalian ACF and CHRAC complexes together with SNF2H, accumulates at DSBs and interacts with Ku70 [71,72]. Depletion of ACF1 and other members of the CHRAC complex leads to increased sensitivity to ionizing radiation, to defects in $\mathrm{Ku} 70$ and Ku80 recruitment and NHEJ, and to HR [72]. ACF1 is also implicated in controlling the G2/M checkpoint [71]. Another binding partner of SNF2H, WSTF/BAZ1B, which is part of the WICH complex, interacts with and phosporylates H2AX on Tyr142 instead of the canonical damage-induced phosphorylation of Ser139 [142]. Importantly, however, depletion of WSTF affects maintenance of H2AX-Ser139 phosporylation and recruitment of active ATM and MDC1 to DSBs. Like SNF2H and ACF1, WSTF is also recruited to DBSs [71]. Together, these data suggest that multiple ISWI chromatin-remodeling complexes act during DSB repair, probably to allow efficient recruitment and maintenance of repair proteins and signaling events (Figure 4).

\section{Discussion and perspectives}

It is clear from the above overview that many different ATP-dependent chromatin-remodeling complexes participate to allow efficient DSB repair and signaling (Figure 4). Although some complexes have been implicated in 
specific repair events or found to be required for altering nucleosome occupancy of DNA surrounding DBSs, the specific activity of most complexes at sites of damage still remains unclear. Furthermore, contradictory results still cause an ongoing debate as to the exact contribution of these complexes to repair [68]. To resolve these issues, and to answer the emerging question why so many complexes are involved, future studies should be aimed at deciphering their specific molecular activity during subsequent repair steps, and at determining the interdependency of different remodeling processes. This will require a multidisciplinary combination of biochemical and cell-biological analysis, incorporating newly developed quantitative proteomic and microscopy techniques. Together, these studies should provide an integrated view on the function and interplay of the multiple chromatin-remodeling complexes and other chromatin modifications that aid repair efficiency.

\section{Conclusion}

NER and DSB repair are in principle independent pathways, and are initiated by entirely distinct DNA damage-sensing mechanisms. Despite this difference, remarkable similar chromatin modifications (such as $\mathrm{H} 2 \mathrm{AX}$ phosphorylation and histone ubiquitylation) and subsequent downstream signaling cascades are triggered by both processes [143-146]. It is surprising to find that, a similar set of upstream chromatin remodelers is used for both efficient repair of single-strand helix-distorting lesions by NER and for repair of DNA DSBs. This suggests that both for initiation and downstream signaling in distinct repair pathways, similar strategies are used. Despite these similarities, significant differences with respect to chromatin modification are also apparent between HR, NHEJ and NER, which are readily visible at the microscopic level [6]. Specifically, HR factors and downstream signaling molecules form large molecular assemblies on chromatin, referred to as ionizing radiation induced foci, which include chromatin changes that are many kilobases to megabases in length $[147,148]$. These microscopic foci are thought to be assembled around DSBs. Strikingly, neither NHEJ nor NER factors form such foci around lesions $[6,15,149]$. Thus, it seems that more or higher-order chromatin modifications are required to allow the complex HR-associated DNA rearrangements, such as homology search, strand annealing, branch migration, and resolution, to occur. This may also be the reason why there are more diverse remodeling complexes in DSB repair. In addition, the repairpatch sizes of NER events are typically around 25 to 30 nucleotides, which is within the range of a single nucleosome, whereas HR involves DNA end-resection and resynthesis of hundreds to thousands of base pairs; therefore it is likely that the latter repair pathway requires more robust chromatin remodeling.

One of the challenges ahead will be to determine at which steps all the different chromatin remodelers actually function in the DDR (either upstream or downstream of repair and/or signaling), and to what extent they function redundantly or influence each other's function. To obtain an integral view on chromatin remodeling associated with the DDR, a systems-biology approach should be applied, by combining detailed genetic and phenotypic analysis with genomic procedures. Because most of the chromatin remodelers have additional functions outside DDR, particularly in transcription regulation, both genome-wide position and gene-expression analysis will be confounded by the fact that an important part of the DDR network is the transcriptional response branch. Although both transcription and DDR require ATP-dependent chromatin remodeling, both chromatin-associated processes are conceptually rather different. Transcription activation occurs in a site-specific and time-dependent manner, and occurs on a gene with an inherent chromatin structure or compaction. By contrast, repair must be able to occur on all genomic locations, at any time [150]. In transcription regulation, the sequential hierarchy by which chromatin structure is altered is difficult to define. As repair takes place at rather diverse chromatin structures, the general concepts and hierarchical molecular mechanism may perhaps be even more difficult to define.

It is likely that many chromatin-remodeling complexes have thus far escaped scrutiny because of redundancy or because they only function in specific chromatin environments, which may not lead to a phenotype that is readily identifiable by genetic screens. Future research should aim to determine whether different complexes are involved in repair of different types of chromatin or in different phases of the cell cycle. In addition, as the DDR is tightly regulated in different cell types involving alternative repair pathways, DDR-associated chromatin changes may also be cell-type-specific [20,151]. It will be interesting to determine to what extent the chromatin landscape and, more specifically, ATP-dependent chromatin-remodeling factors, contribute to DDR differences of different cell types. For instance, we have recently shown that in C. elegans, some SWI/SNF chromatinremodeling subunits are required only for the response of germ cells to UV, while others play a role only in somatic cells (unpublished results; [64]). Some of the contradictory results or interspecies differences observed to date may in fact reflect such differences in cell type and chromatin involvement. Eventually, knowledge about the role that chromatin plays in the DDR might also help us to better understand the etiology of certain 
cancers. Both ATP-dependent chromatin remodeling [152-155] and the DDR [3,5] are implicated in tumorigenesis, but their interplay in this process is still not understood.

\section{List of abbreviations}

64PP: 6-4 photoproducts; CPD: cyclobutane pyrimidine dimer; DDR: DNAdamage response; DSB: double-strand break; GG-NER: global genome nucleotide excision repair; HR: homologous repair; NER: nucleotide excision repair; NHEJ: non-homologous end-joining; PARP: poly(ADP ribose) polymerase; TC-NER: transcription-coupled nucleotide excision repair.

\section{Acknowledgements}

We thank the Association for International Cancer Research (projects 08-0084 and 10-594), the Netherlands Organization for Scientific Research (NWO; projects 863.08.022, 917.96 .120 and 40-00812-98-08031), the Netherlands Genomic Initiative (project 93519021) and the EU funded Network of Excellence LifeSpan (FP6 036894) for financial support.

\section{Authors' contributions}

$\mathrm{HL}$ drafted and edited the manuscript. JAM edited the manuscript and provided artwork. WV helped drafting and edited the manuscript. All authors have read and approved the final manuscript.

\section{Competing interests}

The authors declare that they have no competing interests.

Received: 31 October 2011 Accepted: 30 January 2012

Published: 30 January 2012

\section{References}

1. Lindahl T: Instability and decay of the primary structure of DNA. Nature 1993, 362:709-715.

2. De Bont R, van Larebeke N: Endogenous DNA damage in humans: a review of quantitative data. Mutagenesis 2004, 19:169-185.

3. Hoeijmakers JH: DNA damage, aging, and cancer. N Engl J Med 2009, 361:1475-1485.

4. Ciccia A, Elledge SJ: The DNA damage response: making it safe to play with knives. Mol Cell 2010, 40:179-204.

5. Jackson SP, Bartek J: The DNA-damage response in human biology and disease. Nature 2009, 461:1071-1078.

6. Giglia-Mari G, Zotter A, Vermeulen W: DNA damage response. Cold Spring Harb Perspect Biol 2011.

7. Chodaparambil JV, Edayathumangalam RS, Bao Y, Park YJ, Luger K: Nucleosome structure and function. Ernst Schering Res Found Workshop 2006, 29-46.

8. Happel N, Doenecke D: Histone $\mathrm{H} 1$ and its isoforms: contribution to chromatin structure and function. Gene 2009, 431:1-12.

9. Groth A, Rocha W, Verreault A, Almouzni G: Chromatin challenges during DNA replication and repair. Cell 2007, 128:721-733.

10. Green CM, Almouzni G: When repair meets chromatin. First in series on chromatin dynamics. EMBO Rep 2002, 3:28-33.

11. Gong F, Kwon Y, Smerdon MJ: Nucleotide excision repair in chromatin and the right of entry. DNA Repair (Amst) 2005, 4:884-896.

12. Ransom M, Dennehey BK, Tyler JK: Chaperoning histones during DNA replication and repair. Cell 2010, 140:183-195.

13. Reed SH: Nucleotide excision repair in chromatin: damage removal at the drop of a HAT. DNA Repair (Amst) 2011, 10:734-742.

14. Luijsterburg MS, van Attikum H: Chromatin and the DNA damage response: the cancer connection. Mol Oncol 2011, 5:349-367.

15. Bekker-Jensen S, Mailand N: Assembly and function of DNA double-strand break repair foci in mammalian cells. DNA Repair (Amst) 2010, 9:1219-1228

16. Bell O, Tiwari VK, Thoma NH, Schubeler D: Determinants and dynamics of genome accessibility. Nat Rev Genet 2011, 12:554-564.

17. Hargreaves DC, Crabtree GR: ATP-dependent chromatin remodeling: genetics, genomics and mechanisms. Cell Res 2011, 21:396-420.

18. Clapier CR, Cairns BR: The biology of chromatin remodeling complexes. Annu Rev Biochem 2009, 78:273-304.
19. Flaus A, Owen-Hughes T: Mechanisms for ATP-dependent chromatin remodelling: farewell to the tuna-can octamer? Curr Opin Genet Dev 2004, 14:165-173.

20. Nouspikel T: DNA repair in mammalian cells: Nucleotide excision repair: variations on versatility. Cell Mol Life Sci 2009, 66:994-1009.

21. Sugasawa K, Masutani C, Hanaoka F: Cell-free repair of UV-damaged simian virus 40 chromosomes in human cell extracts. I. Development of a cell-free system detecting excision repair of UV-irradiated SV40 chromosomes. J Biol Chem 1993, 268:9098-9104.

22. Araki M, Masutani C, Maekawa T, Watanabe $Y$, Yamada A, Kusumoto R, Sakai D, Sugasawa K, Ohkuma Y, Hanaoka F: Reconstitution of damage DNA excision reaction from SV40 minichromosomes with purified nucleotide excision repair proteins. Mutat Res 2000, 459:147-160.

23. Osley MA, Tsukuda T, Nickoloff JA: ATP-dependent chromatin remodeling factors and DNA damage repair. Mutat Res 2007, 618:65-80.

24. Cadet J, Sage E, Douki T: Ultraviolet radiation-mediated damage to cellular DNA. Mutat Res 2005, 571:3-17.

25. Mitchell DL, Haipek CA, Clarkson JM: (6-4)Photoproducts are removed from the DNA of UV-irradiated mammalian cells more efficiently than cyclobutane pyrimidine dimers. Mutat Res 1985, 143:109-112.

26. Tijsterman M, de Pril R, Tasseron-de Jong JG, Brouwer J: RNA polymerase II transcription suppresses nucleosomal modulation of UV-induced (6-4) photoproduct and cyclobutane pyrimidine dimer repair in yeast. Mol Cell Biol 1999, 19:934-940.

27. Ruven HJ, Berg RJ, Seelen CM, Dekkers JA, Lohman PH, Mullenders LH, van Zeeland AA: Ultraviolet-induced cyclobutane pyrimidine dimers are selectively removed from transcriptionally active genes in the epidermis of the hairless mouse. Cancer Res 1993, 53:1642-1645.

28. Mitchell DL, Nguyen TD, Cleaver JE: Nonrandom induction of pyrimidinepyrimidone (6-4) photoproducts in ultraviolet-irradiated human chromatin. J Biol Chem 1990, 265:5353-5356.

29. Szymkowski DE, Lawrence CW, Wood RD: Repair by human cell extracts of single (6-4) and cyclobutane thymine-thymine photoproducts in DNA. Proc Natl Acad Sci USA 1993, 90:9823-9827.

30. Suquet C, Mitchell DL, Smerdon MJ: Repair of UV-induced (6-4) photoproducts in nucleosome core DNA. J Biol Chem 1995, 270:16507-16509.

31. Sugasawa K, Okamoto T, Shimizu Y, Masutani C, Iwai S, Hanaoka F: A multistep damage recognition mechanism for global genomic nucleotide excision repair. Genes Dev 2001, 15:507-521.

32. Sugasawa K, Shimizu Y, Iwai S, Hanaoka F: A molecular mechanism for DNA damage recognition by the xeroderma pigmentosum group $C$ protein complex. DNA Repair (Amst) 2002, 1:95-107.

33. Alekseev S, Kool H, Rebel H, Fousteri M, Moser J, Backendorf C, de Gruijl FR, Vrieling $H$, Mullenders LH: Enhanced DDB2 expression protects mice from carcinogenic effects of chronic UV-B irradiation. Cancer Res 2005, 65:10298-10306.

34. Kapetanaki MG, Guerrero-Santoro J, Bisi DC, Hsieh CL, Rapic-Otrin V, Levine AS: The DDB1-CUL4ADDB2 ubiquitin ligase is deficient in xeroderma pigmentosum group $\mathrm{E}$ and targets histone $\mathrm{H} 2 \mathrm{~A}$ at UVdamaged DNA sites. Proc Natl Acad Sci USA 2006, 103:2588-2593.

35. Guerrero-Santoro J, Kapetanaki MG, Hsieh CL, Gorbachinsky I, Levine AS, Rapic-Otrin V: The cullin 4B-based UV-damaged DNA-binding protein ligase binds to UV-damaged chromatin and ubiquitinates histone $\mathrm{H} 2 \mathrm{~A}$. Cancer Res 2008, 68:5014-5022.

36. Fitch ME, Nakajima S, Yasui A, Ford JM: In vivo recruitment of XPC to UVinduced cyclobutane pyrimidine dimers by the DDB2 gene product. Biol Chem 2003, 278:46906-46910.

37. Moser J, Volker M, Kool H, Alekseev S, Vrieling H, Yasui A, van Zeeland AA, Mullenders LH: The UV-damaged DNA binding protein mediates efficient targeting of the nucleotide excision repair complex to UV-induced photo lesions. DNA Repair (Amst) 2005, 4:571-582.

38. Wang $H$, Zhai $L$, Xu J, Joo HY, Jackson $S$, Erdjument-Bromage $H$, Tempst $P$, Xiong $Y$, Zhang $Y$ : Histone $\mathrm{H} 3$ and $\mathrm{H} 4$ ubiquitylation by the CUL4-DDBROC1 ubiquitin ligase facilitates cellular response to DNA damage. Mol Cell 2006, 22:383-394.

39. van Hoffen $A$, Venema J, Meschini $R$, van Zeeland $A A$, Mullenders $L H$ : Transcription-coupled repair removes both cyclobutane pyrimidine dimers and 6-4 photoproducts with equal efficiency and in a sequential way from transcribed DNA in xeroderma pigmentosum group $C$ fibroblasts. EMBO J 1995, 14:360-367. 
40. Mellon I, Spivak G, Hanawalt PC: Selective removal of transcriptionblocking DNA damage from the transcribed strand of the mammalian DHFR gene. Cell 1987, 51:241-249.

41. Duan MR, Smerdon MJ: UV damage in DNA promotes nucleosome unwrapping. J Biol Chem 2010, 285:26295-26303.

42. Muftuoglu M, Selzer R, Tuo J, Brosh RM Jr, Bohr VA: Phenotypic consequences of mutations in the conserved motifs of the putative helicase domain of the human Cockayne syndrome group B gene. Gene 2002, 283:27-40

43. Citterio E, Rademakers S, van der Horst GT, van Gool AJ, Hoeijmakers JH, Vermeulen W: Biochemical and biological characterization of wild-type and ATPase-deficient Cockayne syndrome B repair protein. $J$ Biol Chem 1998, 273:11844-11851.

44. Selzer RR, Nyaga S, Tuo J, May A, Muftuoglu M, Christiansen M, Citterio E, Brosh RM Jr, Bohr VA: Differential requirement for the ATPase domain of the Cockayne syndrome group B gene in the processing of UV-induced DNA damage and 8-oxoguanine lesions in human cells. Nucleic Acids Res 2002, 30:782-793.

45. Lake RJ, Geyko A, Hemashettar G, Zhao Y, Fan HY: UV-induced association of the CSB remodeling protein with chromatin requires ATP-dependent relief of N-terminal autorepression. Mol Cell 2010, 37:235-246.

46. Citterio E, Van Den Boom V, Schnitzler G, Kanaar R, Bonte E, Kingston RE, Hoeijmakers JH, Vermeulen W: ATP-dependent chromatin remodeling by the Cockayne syndrome $B$ DNA repair-transcription-coupling factor. $\mathrm{Mol}$ Cell Biol 2000, 20:7643-7653.

47. Fousteri M, Vermeulen W, van Zeeland AA, Mullenders LH: Cockayne syndrome $A$ and $B$ proteins differentially regulate recruitment of chromatin remodeling and repair factors to stalled RNA polymerase II in vivo. Mol Cell 2006, 23:471-482.

48. Bang DD, Verhage R, Goosen N, Brouwer J, van de Putte P: Molecular cloning of RAD16, a gene involved in differential repair in Saccharomyces cerevisiae. Nucleic Acids Res 1992, 20:3925-3931.

49. Verhage R, Zeeman AM, de Groot N, Gleig F, Bang DD, van de Putte P, Brouwer J: The RAD7 and RAD16 genes, which are essential for pyrimidine dimer removal from the silent mating type loci, are also required for repair of the nontranscribed strand of an active gene in Saccharomyces cerevisiae. Mol Cell Biol 1994, 14:6135-6142.

50. Yu S, Owen-Hughes T, Friedberg EC, Waters R, Reed SH: The yeast Rad7/ Rad16/Abf1 complex generates superhelical torsion in DNA that is required for nucleotide excision repair. DNA Repair (Amst) 2004, 3:277-287.

51. Yu S, Smirnova JB, Friedberg EC, Stillman B, Akiyama M, Owen-Hughes T, Waters R, Reed SH: ABF1-binding sites promote efficient global genome nucleotide excision repair. J Biol Chem 2009, 284:966-973.

52. Yu Y, Teng Y, Liu H, Reed SH, Waters R: UV irradiation stimulates histone acetylation and chromatin remodeling at a repressed yeast locus. Proc Natl Acad Sci USA 2005, 102:8650-8655.

53. Teng Y, Liu H, Gill HW, Yu Y, Waters R, Reed SH: Saccharomyces cerevisiae Rad16 mediates ultraviolet-dependent histone $\mathrm{H} 3$ acetylation required for efficient global genome nucleotide-excision repair. EMBO Rep 2008, 9:97-102.

54. $Y u$ S, Teng $Y$, Waters $R$, Reed SH: How chromatin is remodelled during DNA repair of UV-induced DNA damage in Saccharomyces cerevisiae. PLoS Genet 2011, 7:e1002124.

55. Hara R, Sancar A: The SWI/SNF chromatin-remodeling factor stimulates repair by human excision nuclease in the mononucleosome core particle. Mol Cell Biol 2002, 22:6779-6787.

56. Hara R, Sancar A: Effect of damage type on stimulation of human excision nuclease by SWI/SNF chromatin remodeling factor. Mol Cell Biol 2003, 23:4121-4125.

57. Gong F, Fahy D, Smerdon MJ: Rad4-Rad23 interaction with SWI/SNF links ATP-dependent chromatin remodeling with nucleotide excision repair. Nat Struct Mol Biol 2006, 13:902-907.

58. Zhang L, Zhang Q, Jones K, Patel M, Gong F: The chromatin remodeling factor BRG1 stimulates nucleotide excision repair by facilitating recruitment of XPC to sites of DNA damage. Cell Cycle 2009, 8:3953-3959.

59. Zhao Q, Wang QE, Ray A, Wani G, Han C, Milum K, Wani AA: Modulation of nucleotide excision repair by mammalian SWI/SNF chromatinremodeling complex. J Biol Chem 2009, 284:30424-30432.

60. Gong F, Fahy D, Liu H, Wang W, Smerdon MJ: Role of the mammalian SWI/SNF chromatin remodeling complex in the cellular response to UV damage. Cell Cycle 2008, 7:1067-1074.
61. Ray A, Mir SN, Wani G, Zhao Q, Battu A, Zhu Q, Wang QE, Wani AA: Human SNF5/INI1, a component of the human SWI/SNF chromatin remodeling complex, promotes nucleotide excision repair by influencing ATM recruitment and downstream H2AX phosphorylation. Mol Cell Biol 2009, 29:6206-6219.

62. Klochendler-Yeivin A, Picarsky E, Yaniv M: Increased DNA damage sensitivity and apoptosis in cells lacking the Snf5/Ini1 subunit of the SWI/SNF chromatin remodeling complex. Mol Cell Biol 2006, 26:2661-2674.

63. McKenna ES, Sansam CG, Cho YJ, Greulich H, Evans JA, Thom CS, Moreau LA, Biegel JA, Pomeroy SL, Roberts CW: Loss of the epigenetic tumor suppressor SNF5 leads to cancer without genomic instability. Mol Cell Biol 2008, 28:6223-6233.

64. Lans H, Marteijn JA, Schumacher B, Hoeijmakers JH, Jansen G, Vermeulen W: Involvement of global genome repair, transcription coupled repair, and chromatin remodeling in UV DNA damage response changes during development. PLoS Genet 2010, 6:e1000941.

65. Shen X, Mizuguchi G, Hamiche A, Wu C: A chromatin remodelling complex involved in transcription and DNA processing. Nature 2000, 406:541-544.

66. Wu S, Shi Y, Mulligan P, Gay F, Landry J, Liu H, Lu J, Qi HH, Wang W, Nickoloff JA, Wu C: A YY1-INO80 complex regulates genomic stability through homologous recombination-based repair. Nat Struct Mol Biol 2007, 14:1165-1172.

67. Sarkar S, Kiely R, McHugh PJ: The Ino80 chromatin-remodeling complex restores chromatin structure during UV DNA damage repair. J Cell Biol 2010, 191:1061-1068.

68. Czaja W, Bespalov VA, Hinz JM, Smerdon MJ: Proficient repair in chromatin remodeling defective ino80 mutants of Saccharomyces cerevisiae highlights replication defects as the main contributor to DNA damage sensitivity. DNA Repair (Amst) 2010, 9:976-984.

69. Jiang $Y$, Wang X, Bao S, Guo R, Johnson DG, Shen X, Li L: INO80 chromatin remodeling complex promotes the removal of UV lesions by the nucleotide excision repair pathway. Proc Natl Acad Sci USA 2010, 107:17274-17279.

70. Ura K, Araki M, Saeki H, Masutani C, Ito T, Iwai S, Mizukoshi T, Kaneda Y, Hanaoka F: ATP-dependent chromatin remodeling facilitates nucleotide excision repair of UV-induced DNA lesions in synthetic dinucleosomes. Embo J 2001, 20:2004-2014.

71. Sanchez-Molina S, Mortusewicz O, Bieber B, Auer S, Eckey M, Leonhardt H, Friedl AA, Becker PB: Role for hACF1 in the G2/M damage checkpoint. Nucleic Acids Res 2011, 39(19):8445-56.

72. Lan L, Ui A, Nakajima S, Hatakeyama K, Hoshi M, Watanabe R, Janicki SM, Ogiwara H, Kohno T, Kanno S, Yasui A: The ACF1 complex is required for DNA double-strand break repair in human cells. Mol Cell 2010, 40:976-987.

73. Cavellan E, Asp P, Percipalle P, Farrants AK: The WSTF-SNF2h chromatin remodeling complex interacts with several nuclear proteins in transcription. J Biol Chem 2006, 281:16264-16271.

74. Luijsterburg MS, Dinant C, Lans H, Stap J, Wiernasz E, Lagerwerf S, Warmerdam DO, Lindh M, Brink MC, Dobrucki JW, et al: Heterochromatin protein 1 is recruited to various types of DNA damage. J Cell Biol 2009, 185:577-586.

75. Guo R, Chen J, Mitchell DL, Johnson DG: GCN5 and E2F1 stimulate nucleotide excision repair by promoting $\mathrm{H} 3 \mathrm{~K} 9$ acetylation at sites of damage. Nucleic Acids Res 2011, 39:1390-1397.

76. Baxter BK, Smerdon MJ: Nucleosome unfolding during DNA repair in normal and xeroderma pigmentosum (group C) human cells. J Biol Chem 1998, 273:17517-17524.

77. Gaillard PH, Martini EM, Kaufman PD, Stillman B, Moustacchi E, Almouzni G: Chromatin assembly coupled to DNA repair: a new role for chromatin assembly factor I. Cell 1996, 86:887-896.

78. Green CM, Almouzni G: Local action of the chromatin assembly factor CAF-1 at sites of nucleotide excision repair in vivo. EMBO J 2003, 22:5163-5174.

79. Polo SE, Roche D, Almouzni G: New histone incorporation marks sites of UV repair in human cells. Cell 2006, 127:481-493.

80. San Filippo J, Sung P, Klein H: Mechanism of eukaryotic homologous recombination. Annu Rev Biochem 2008, 77:229-257.

81. Lieber MR: The mechanism of double-strand DNA break repair by the nonhomologous DNA end-joining pathway. Annu Rev Biochem 2010, 79:181-211. 
82. Kinner A, Wu W, Staudt C, lliakis G: Gamma-H2AX in recognition and signaling of DNA double-strand breaks in the context of chromatin. Nucleic Acids Res 2008, 36:5678-5694.

83. Murga M, Jaco I, Fan Y, Soria R, Martinez-Pastor B, Cuadrado M, Yang SM, Blasco MA, Skoultchi Al, Fernandez-Capetillo O: Global chromatin compaction limits the strength of the DNA damage response. J Cell Biol 2007, 178:1101-1108

84. Goodarzi AA, Kurka T, Jeggo PA: KAP-1 phosphorylation regulates CHD3 nucleosome remodeling during the DNA double-strand break response. Nat Struct Mol Biol 2011, 18:831-839.

85. Goodarzi AA, Noon AT, Deckbar D, Ziv Y, Shiloh Y, Lobrich M, Jeggo PA: ATM signaling facilitates repair of DNA double-strand breaks associated with heterochromatin. Mol Cell 2008, 31:167-177.

86. Takahashi K, Kaneko I: Changes in nuclease sensitivity of mammalian cells after irradiation with 60Co gamma-rays. Int J Radiat Biol Relat Stud Phys Chem Med 1985, 48:389-395.

87. Ziv Y, Bielopolski D, Galanty Y, Lukas C, Taya Y, Schultz DC, Lukas J, BekkerJensen S, Bartek J, Shiloh Y: Chromatin relaxation in response to DNA double-strand breaks is modulated by a novel ATM- and KAP-1 dependent pathway. Nat Cell Biol 2006, 8:870-876.

88. Kruhlak MJ, Celeste A, Dellaire G, Fernandez-Capetillo O, Muller WG, McNally JG, Bazett-Jones DP, Nussenzweig A: Changes in chromatin structure and mobility in living cells at sites of DNA double-strand breaks. J Cell Biol 2006, 172:823-834.

89. Agarwal S, van Cappellen WA, Guenole A, Eppink B, Linsen SE, Meijering E, Houtsmuller A, Kanaar R, Essers J: ATP-dependent and independent functions of Rad54 in genome maintenance. J Cell Biol 2011, 192:735-750.

90. Mazin AV, Mazina OM, Bugreev DV, Rossi MJ: Rad54, the motor of homologous recombination. DNA Repair (Amst) 2010, 9:286-302.

91. Bugreev DV, Mazina OM, Mazin AV: Rad54 protein promotes branch migration of Holliday junctions. Nature 2006, 442:590-593.

92. Chai B, Huang J, Cairns BR, Laurent BC: Distinct roles for the RSC and Swi/ Snf ATP-dependent chromatin remodelers in DNA double-strand break repair. Genes Dev 2005, 19:1656-1661.

93. Sinha M, Watanabe S, Johnson A, Moazed D, Peterson CL: Recombinational repair within heterochromatin requires ATP-dependent chromatin remodeling. Cell 2009, 138:1109-1121.

94. Koyama H, Itoh M, Miyahara K, Tsuchiya E: Abundance of the RSC nucleosome-remodeling complex is important for the cells to tolerate DNA damage in Saccharomyces cerevisiae. FEBS Lett 2002, 531:215-221.

95. Shim EY, Ma JL, Oum JH, Yanez Y, Lee SE: The yeast chromatin remodeler RSC complex facilitates end joining repair of DNA double-strand breaks. Mol Cell Biol 2005, 25:3934-3944.

96. Oum JH, Seong C, Kwon Y, Ji JH, Sid A, Ramakrishnan S, Ira G, Malkova A, Sung P, Lee SE, Shim EY: RSC Facilitates Rad59-Dependent homologous recombination between sister chromatids by promoting cohesin loading at DNA double-strand breaks. Mol Cell Biol 2011.

97. Shim EY, Hong SJ, Oum JH, Yanez Y, Zhang Y, Lee SE: RSC mobilizes nucleosomes to improve accessibility of repair machinery to the damaged chromatin. Mol Cell Biol 2007, 27:1602-1613.

98. Liang B, Qiu J, Ratnakumar K, Laurent BC: RSC functions as an early double-strand-break sensor in the cell's response to DNA damage. Curr Biol 2007, 17:1432-1437.

99. Kent NA, Chambers AL, Downs JA: Dual chromatin remodeling roles for RSC during DNA double strand break induction and repair at the yeast MAT locus. J Biol Chem 2007, 282:27693-27701.

100. Park JH, Park EJ, Lee HS, Kim SJ, Hur SK, Imbalzano AN, Kwon J: Mammalian SWI/SNF complexes facilitate DNA double-strand break repair by promoting gamma-H2AX induction. EMBO J 2006, 25:3986-3997.

101. Park JH, Park EJ, Hur SK, Kim S, Kwon J: Mammalian SWI/SNF chromatin remodeling complexes are required to prevent apoptosis after DNA damage. DNA Repair (Amst) 2009, 8:29-39.

102. Lee HS, Park JH, Kim SJ, Kwon SJ, Kwon J: A cooperative activation loop among SWI/SNF, gamma-H2AX and $\mathrm{H} 3$ acetylation for DNA doublestrand break repair. EMBO J 2010, 29:1434-1445.

103. Ogiwara H, Ui A, Otsuka A, Satoh H, Yokomi I, Nakajima S, Yasui A Yokota J, Kohno T: Histone acetylation by CBP and p300 at doublestrand break sites facilitates SWI/SNF chromatin remodeling and the recruitment of non-homologous end joining factors. Oncogene 2011, 30:2135-2146.
104. Peng G, Yim EK, Dai H, Jackson AP, Burgt I, Pan MR, Hu R, Li K, Lin SY: BRIT1/MCPH1 links chromatin remodelling to DNA damage response. Nat Cell Biol 2009, 11:865-872.

105. Morrison AJ, Highland J, Krogan NJ, Arbel-Eden A, Greenblatt JF, Haber JE, Shen X: INO80 and gamma-H2AX interaction links ATP-dependent chromatin remodeling to DNA damage repair. Cell 2004, 119:767-775.

106. van Attikum H, Fritsch O, Hohn B, Gasser SM: Recruitment of the INO80 complex by $\mathrm{H} 2 \mathrm{~A}$ phosphorylation links ATP-dependent chromatin remodeling with DNA double-strand break repair. Cell 2004, 119:777-788.

107. Kawashima S, Ogiwara H, Tada S, Harata M, Wintersberger U, Enomoto T, Seki M: The INO80 complex is required for damage-induced recombination. Biochem Biophys Res Commun 2007, 355:835-841.

108. Tsukuda T, Fleming AB, Nickoloff JA, Osley MA: Chromatin remodelling at a DNA double-strand break site in Saccharomyces cerevisiae. Nature 2005, 438:379-383.

109. van Attikum H, Fritsch O, Gasser SM: Distinct roles for SWR1 and INO80 chromatin remodeling complexes at chromosomal double-strand breaks. EMBO J 2007, 26:4113-4125.

110. Falbo KB, Alabert C, Katou Y, Wu S, Han J, Wehr T, Xiao J, He X, Zhang Z, Shi $Y$, et al: Involvement of a chromatin remodeling complex in damage tolerance during DNA replication. Nat Struct Mol Biol 2009, 16:1167-1172.

111. Tsukuda T, Lo YC, Krishna S, Sterk R, Osley MA, Nickoloff JA: INO80dependent chromatin remodeling regulates early and late stages of mitotic homologous recombination. DNA Repair (Amst) 2009, 8:360-369.

112. Papamichos-Chronakis M, Krebs JE, Peterson CL: Interplay between Ino80 and Swr1 chromatin remodeling enzymes regulates cell cycle checkpoint adaptation in response to DNA damage. Genes Dev 2006, 20:2437-2449.

113. Downs JA, Allard S, Jobin-Robitaille O, Javaheri A, Auger A, Bouchard N, Kron SJ, Jackson SP, Cote J: Binding of chromatin-modifying activities to phosphorylated histone H2A at DNA damage sites. Mol Cell 2004, 16:979-990.

114. Papamichos-Chronakis M, Watanabe S, Rando OJ, Peterson CL: Global regulation of $\mathrm{H} 2 \mathrm{~A} . \mathrm{Z}$ localization by the INO80 chromatin-remodeling enzyme is essential for genome integrity. Cell 2011, 144:200-213.

115. Kashiwaba S, Kitahashi K, Watanabe T, Onoda F, Ohtsu M, Murakami Y: The mammalian INO80 complex is recruited to DNA damage sites in an ARP8 dependent manner. Biochem Biophys Res Commun 2010, 402:619-625.

116. Kitayama K, Kamo M, Oma Y, Matsuda R, Uchida T, Ikura T, Tashiro S, Ohyama T, Winsor B, Harata M: The human actin-related protein hArp5: nucleo-cytoplasmic shuttling and involvement in DNA repair. Exp Cell Res 2009, 315:206-217

117. Gospodinov A, Tsaneva I, Anachkova B: RAD51 foci formation in response to DNA damage is modulated by TIP49. Int J Biochem Cell Biol 2009, 41:925-933.

118. Park EJ, Hur SK, Kwon J: Human INO80 chromatin-remodelling complex contributes to DNA double-strand break repair via the expression of Rad54B and XRCC3 genes. Biochem J 2010, 431:179-187.

119. Xu Y, Sun Y, Jiang X, Ayrapetov MK, Moskwa P, Yang S, Weinstock DM, Price BD: The p400 ATPase regulates nucleosome stability and chromatin ubiquitination during DNA repair. J Cell Biol 2010, 191:31-43.

120. Murr R, Loizou Jl, Yang YG, Cuenin C, Li H, Wang ZQ, Herceg Z: Histone acetylation by Trrap-Tip60 modulates loading of repair proteins and repair of DNA double-strand breaks. Nat Cell Biol 2006, 8:91-99.

121. Gorrini C, Squatrito M, Luise C, Syed N, Perna D, Wark L, Martinato F, Sardella D, Verrecchia A, Bennett S, et al: Tip60 is a haplo-insufficient tumour suppressor required for an oncogene-induced DNA damage response. Nature 2007, 448:1063-1067.

122. Bird AW, Yu DY, Pray-Grant MG, Qiu Q, Harmon KE, Megee PC, Grant PA, Smith MM, Christman MF: Acetylation of histone H4 by Esa1 is required for DNA double-strand break repair. Nature 2002, 419:411-415.

123. Sun $Y$, Jiang $X$, Chen $S$, Fernandes $N$, Price BD: A role for the Tip60 histone acetyltransferase in the acetylation and activation of ATM. Proc Natl Acad Sci USA 2005, 102:13182-13187.

124. Sun $Y$, Jiang $X, X u Y$, Ayrapetov MK, Moreau LA, Whetstine JR, Price BD: Histone $\mathrm{H} 3$ methylation links DNA damage detection to activation of the tumour suppressor Tip60. Nat Cell Biol 2009, 11:1376-1382.

125. Kusch T, Florens L, Macdonald WH, Swanson SK, Glaser RL, Yates JR, Abmayr SM, Washburn MP, Workman JL: Acetylation by Tip60 is required 
for selective histone variant exchange at DNA lesions. Science 2004, 306:2084-2087.

126. van Haaften G, Romeijn R, Pothof J, Koole W, Mullenders LH, Pastink A, Plasterk RH, Tijsterman M: Identification of conserved pathways of DNAdamage response and radiation protection by genome-wide RNAi. Curr Biol 2006, 16:1344-1350.

127. Pegoraro G, Kubben N, Wickert U, Gohler H, Hoffmann K, Misteli T: Ageingrelated chromatin defects through loss of the NURD complex. Nat Cell Biol 2009, 11:1261-1267.

128. Smeenk G, Wiegant WW, Vrolijk H, Solari AP, Pastink A, van Attikum H: The NuRD chromatin-remodeling complex regulates signaling and repair of DNA damage. J Cell Biol 2010, 190:741-749.

129. Polo SE, Kaidi A, Baskcomb L, Galanty Y, Jackson SP: Regulation of DNAdamage responses and cell-cycle progression by the chromatin remodelling factor CHD4. EMBO J 2010, 29:3130-3139.

130. Larsen DH, Poinsignon C, Gudjonsson T, Dinant C, Payne MR, Hari FJ, Danielsen JM, Menard P, Sand JC, Stucki M, et al: The chromatinremodeling factor CHD4 coordinates signaling and repair after DNA damage. J Cell Biol 2010, 190:731-740.

131. Chou DM, Adamson B, Dephoure NE, Tan X, Nottke AC, Hurov KE, Gygi SP, Colaiacovo MP, Elledge SJ: A chromatin localization screen reveals poly (ADP ribose)-regulated recruitment of the repressive polycomb and NuRD complexes to sites of DNA damage. Proc Natl Acad Sci USA 2010, 107:18475-18480.

132. Ahel D, Horejsi Z, Wiechens N, Polo SE, Garcia-Wilson E, Ahel I, Flynn H, Skehel M, West SC, Jackson SP, et al: Poly(ADP-ribose)-dependent regulation of DNA repair by the chromatin remodeling enzyme ALC1. Science 2009, 325:1240-1243.

133. Gottschalk AJ, Timinszky G, Kong SE, Jin J, Cai Y, Swanson SK, Washburn MP, Florens L, Ladurner AG, Conaway JW, Conaway RC: Poly (ADP-ribosyl)ation directs recruitment and activation of an ATPdependent chromatin remodeler. Proc Natl Acad Sci USA 2009, 106:13770-13774.

134. Iles N, Rulten S, El-Khamisy SF, Caldecott KW: APLF (C2orf13) is a novel human protein involved in the cellular response to chromosomal DNA strand breaks. Mol Cell Biol 2007, 27:3793-3803.

135. Rulten SL, Fisher AE, Robert I, Zuma MC, Rouleau M, Ju L, Poirier G, ReinaSan-Martin B, Caldecott KW: PARP-3 and APLF function together to accelerate nonhomologous end-joining. Mol Cell 2011, 41:33-45.

136. Mehrotra PV, Ahel D, Ryan DP, Weston R, Wiechens N, Kraehenbuehl R, Owen-Hughes T, Ahel I: DNA repair factor APLF is a histone chaperone. Mol Cell 2011, 41:46-55.

137. Nagarajan P, Onami TM, Rajagopalan S, Kania S, Donnell R, Venkatachalam S: Role of chromodomain helicase DNA-binding protein 2 in DNA damage response signaling and tumorigenesis. Oncogene 2009, 28:1053-1062.

138. Erdel F, Rippe K: Binding kinetics of human ISWI chromatin-remodelers to DNA repair sites elucidate their target location mechanism. Nucleus 2011, 2:105-112

139. Erdel F, Schubert T, Marth C, Langst G, Rippe K: Human ISWI chromatinremodeling complexes sample nucleosomes via transient binding reactions and become immobilized at active sites. Proc Natl Acad Sci USA 2010, 107:19873-19878.

140. Ye Y, Xiao Y, Wang W, Wang Q, Yearsley K, Wani AA, Yan Q, Gao JX, Shetuni BS, Barsky SH: Inhibition of expression of the chromatin remodeling gene, SNF2L, selectively leads to DNA damage, growth inhibition, and cancer cell death. Mol Cancer Res 2009, 7:1984-1999.

141. Nakamura K, Kato A, Kobayashi J, Yanagihara H, Sakamoto S, Oliveira DV, Shimada M, Tauchi H, Suzuki H, Tashiro S, et al: Regulation of homologous recombination by RNF20-dependent H2B ubiquitination. Mol Cell 2011, 41:515-528.

142. Xiao A, Li H, Shechter D, Ahn SH, Fabrizio LA, Erdjument-Bromage H, IshibeMurakami S, Wang B, Tempst P, Hofmann $\mathrm{K}$, et al: WSTF regulates the H2A. $X$ DNA damage response via a novel tyrosine kinase activity. Nature 2009, 457:57-62.

143. Marteijn JA, Bekker-Jensen S, Mailand N, Lans H, Schwertman P, Gourdin AM, Dantuma NP, Lukas J, Vermeulen W: Nucleotide excision repair-induced $\mathrm{H} 2 \mathrm{~A}$ ubiquitination is dependent on MDC1 and RNF8 and reveals a universal DNA damage response. J Cell Biol 2009, 186:835-847.
144. Hanasoge $\mathrm{S}$, Ljungman M: H2AX phosphorylation after UV irradiation is triggered by DNA repair intermediates and is mediated by the ATR kinase. Carcinogenesis 2007, 28:2298-2304.

145. Matsumoto M, Yaginuma K, Igarashi A, Imura M, Hasegawa M, Iwabuchi K, Date T, Mori T, Ishizaki K, Yamashita K, et al: Perturbed gap-filling synthesis in nucleotide excision repair causes histone H2AX phosphorylation in human quiescent cells. J Cell Sci 2007, 120:1104-1112.

146. O'Driscoll M, Ruiz-Perez VL, Woods CG, Jeggo PA, Goodship JA: A splicing mutation affecting expression of ataxia-telangiectasia and Rad3-related protein (ATR) results in Seckel syndrome. Nat Genet 2003, 33:497-501.

147. Rogakou EP, Boon C, Redon C, Bonner WM: Megabase chromatin domains involved in DNA double-strand breaks in vivo. J Cell Biol 1999, 146:905-916.

148. Shroff R, Arbel-Eden A, Pilch D, Ira G, Bonner WM, Petrini JH, Haber JE, Lichten M: Distribution and dynamics of chromatin modification induced by a defined DNA double-strand break. Curr Biol 2004, 14:1703-1711.

149. Vermeulen W: Dynamics of mammalian NER proteins. DNA Repair (Amst) 2011, 10:760-771.

150. Essers J, Vermeulen W, Houtsmuller AB: DNA damage repair: anytime, anywhere? Curr Opin Cell Biol 2006, 18:240-246.

151. Shrivastav M, De Haro LP, Nickoloff JA: Regulation of DNA double-strand break repair pathway choice. Cell Res 2008, 18:134-147.

152. Reisman D, Glaros S, Thompson EA: The SWI/SNF complex and cancer. Oncogene 2009, 28:1653-1668.

153. Shih le M, Davidson B: Pathogenesis of ovarian cancer: clues from selected overexpressed genes. Future Oncol 2009, 5:1641-1657.

154. Stopka T, Zakova D, Fuchs O, Kubrova O, Blafkova J, Jelinek J, Necas E, Zivny J: Chromatin remodeling gene SMARCA5 is dysregulated in primitive hematopoietic cells of acute leukemia. Leukemia 2000, 14:1247-1252.

155. Wang GG, Allis CD, Chi P: Chromatin remodeling and cancer, Part II: ATPdependent chromatin remodeling. Trends Mol Med 2007, 13:373-380.

156. Wyman C, Kanaar R: DNA double-strand break repair: all's well that ends well. Annu Rev Genet 2006, 40:363-383.

157. Mohrmann L, Verrijzer CP: Composition and functional specificity of SWI2/ SNF2 class chromatin remodeling complexes. Biochim Biophys Acta 2005, 1681:59-73.

158. Bao Y, Shen X: INO80 subfamily of chromatin remodeling complexes. Mutat Res 2007, 618:18-29.

159. Marfella CG, Imbalzano AN: The Chd family of chromatin remodelers. Mutat Res 2007, 618:30-40

160. Corona DF, Tamkun JW: Multiple roles for ISWI in transcription, chromosome organization and DNA replication. Biochim Biophys Acta 2004, 1677:113-119.

161. van Gool AJ, Verhage R, Swagemakers SM, van de Putte P, Brouwer J, Troelstra C, Bootsma D, Hoeijmakers JH: RAD26, the functional S. cerevisiae homolog of the Cockayne syndrome B gene ERCC6. Embo J 1994, 13:5361-5369.

162. Johnson RE, Henderson ST, Petes TD, Prakash S, Bankmann M, Prakash L: Saccharomyces cerevisiae RAD5-encoded DNA repair protein contains DNA helicase and zinc-binding sequence motifs and affects the stability of simple repetitive sequences in the genome. Mol Cell Biol 1992, 12:3807-3818.

163. Petukhova G, Van Komen S, Vergano S, Klein H, Sung P: Yeast Rad54 promotes Rad51-dependent homologous DNA pairing via ATP hydrolysis-driven change in DNA double helix conformation. I Biol Chem 1999, 274:29453-29462.

164. Klein HL: RDH54, a RAD54 homologue in Saccharomyces cerevisiae, is required for mitotic diploid-specific recombination and repair and for meiosis. Genetics 1997, 147:1533-1543.

165. Troelstra C, van Gool A, de Wit J, Vermeulen W, Bootsma D, Hoeijmakers JH: ERCC6, a member of a subfamily of putative helicases, is involved in Cockayne's syndrome and preferential repair of active genes. Cell 1992, 71:939-953.

166. Iyer LM, Babu MM, Aravind L: The HIRAN domain and recruitment of chromatin remodeling and repair activities to damaged DNA. Cell Cycle 2006, 5:775-782

167. Lin JR, Zeman MK, Chen JY, Yee MC, Cimprich KA: SHPRH and HLTF act in a damage-specific manner to coordinate different forms of postreplication repair and prevent mutagenesis. Mol Cell 2011, 42:237-249. 
168. Essers J, Hendriks RW, Swagemakers SM, Troelstra C, de Wit J, Bootsma D, Hoeijmakers JH, Kanaar R: Disruption of mouse RAD54 reduces ionizing radiation resistance and homologous recombination. Cell 1997, 89:195-204.

169. Miyagawa K, Tsuruga T, Kinomura A, Usui K, Katsura M, Tashiro S, Mishima $H$, Tanaka $K$ : A role for RAD54B in homologous recombination in human cells. EMBO J 2002, 21:175-180.

170. Tanaka K, Kagawa W, Kinebuchi T, Kurumizaka H, Miyagawa K: Human Rad54B is a double-stranded DNA-dependent ATPase and has biochemical properties different from its structural homolog in yeast, Tid1/Rdh54. Nucleic Acids Res 2002, 30:1346-1353.

171. Wesoly J, Agarwal S, Sigurdsson S, Bussen W, Van Komen S, Qin J, van Steeg $H$, van Benthem J, Wassenaar E, Baarends WM, et al: Differential contributions of mammalian Rad54 paralogs to recombination, DNA damage repair, and meiosis. Mol Cell Biol 2006, 26:976-989.

172. Motegi A, Liaw HJ, Lee KY, Roest HP, Maas A, Wu X, Moinova H, Markowitz SD, Ding H, Hoeijmakers JH, Myung K: Polyubiquitination of proliferating cell nuclear antigen by HLTF and SHPRH prevents genomic instability from stalled replication forks. Proc Natl Acad Sci USA 2008, 105:12411-12416.

173. Postow L, Woo EM, Chait BT, Funabiki H: Identification of SMARCAL1 as a component of the DNA damage response. J Biol Chem 2009, 284:35951-35961.

174. Yusufzai T, Kong $X$, Yokomori K, Kadonaga JT: The annealing helicase HARP is recruited to DNA repair sites via an interaction with RPA. Genes Dev 2009, 23:2400-2404.

doi:10.1186/1756-8935-5-4

Cite this article as: Lans et al: ATP-dependent chromatin remodeling in the DNA-damage response. Epigenetics \& Chromatin 2012 5:4.

\section{Submit your next manuscript to BioMed Central} and take full advantage of:

- Convenient online submission

- Thorough peer review

- No space constraints or color figure charges

- Immediate publication on acceptance

- Inclusion in PubMed, CAS, Scopus and Google Scholar

- Research which is freely available for redistribution

Submit your manuscript at www.biomedcentral.com/submit
Biomed Central 